\title{
THE ETHICAL VIEWS OF THE THINKER AND POET BOBORAKHIM MASHRAB
}

\author{
Mumin Khoshimhonov,
}

Candidate of Philosophical Sciences, assistant professor at Jizzakh State Pedagogical Institute named after Abdulla Kodiriy, Republic of Uzbekistan

\section{http://dx.doi.org/10.26739/2573-5616-2017-8-8-8}

\section{ABSTRACT}

This article analyses the life and work of the great Sufi, poet, globetrotter in social-moral history of the Central Asia countries Boborakhim Mashrab, his travels in the East countries, left social-cultural, religious-moral content and essence extant to out days, his influence in education of the perfect person.

Also considered studies of the East, Russian and Western scientists, the importance of the universal humanistic nature of the poet's heritage, the importance of ethical views.

Keywords: Philosopher, religion, Sufi, Allah, father, mother, Koran, "Mabdai nur", "Kimyo"("Chemistry"), Alisher Navoi, devona(moonstruck) Mashrab, shah(king) Mashrab, mulla Bazar Ahund, Ofokhoja, Kashkar, Yorkent.

Imom Buhoriy, Burkhoniddin Marginoni, Isova Khakim Termizi, Makhmud Zamakhshari, Mukhammad Kaffol Shoshi, Vakhouddin Nakshband, Hoja Akhror Vali, Mukhammad Horazmi, Akhmad Fargoni, Boborakhim Mashrab and other names of many geniuses not only in Islam, 
but also in the history of world civilization, rightly written with golden letters. In a great history, nothing vanishes without a trace. It is stored in the bloodstream of nations, historical memories and demonstrated in theirdeeds. That is why it is powerful. Preserve, study, and leave the historical heritage from generation to generation, it is one of the most important and urgent priorities of our government policy.

Boborakhim Mashrab, as one of the great representatives of the Uzbek classic literature, who through the ages illuminated our spirit with his light, and pleased our people with his attractive gazals. He is also a Sufi, poetlyricist and philosopher, and also philanthropist and free-thinkerstandardbearer, a self-sacrificing fighter against injustice, a public figure who made a great contribution to the development of Movarounnakhr. ${ }^{1}$

It is difficult to imagine social and scientific thinking of the XVII-XVIII centuries of the Ashtarhan period without playful gazals of talented poet Boborakhim Mashrab, who left rich heritage.

Mashrab's first teacher, mulla Bozor Ohund, was educated in Bukhara for a long time and was a model student, and was known as an attentive and honorable person in the Namangan environment.

In fact, teacher, mulla Bozor Ohund could not teach him anymore because of Mashrab's innate ability to remember, he gave him all the knowledge he possessed, and let Mashrab havemore knowledge than he could give him, he sent him to Kashgar as a pupil to spiritual mentor Ofokhoja, who was not only a prominent figure, but also he was a saint, who had a great authority in the social- political environment in Kashkar and Yorkent regions.

When Mashrab returned to Namangan in 1690, his fathermulla Vali died, his mother Salimabibi and his sister Mokhibadr were alive. The long time loss of son made mother ill, and owing to return of the saint, she again regained. Mother died with a suffer of separation. Mashrab left his sick sister Mokhibadr to his close relatives and went to a long journey in 1691 . He was in all the provinces of Movarounnahr in those years. From the poems in the stories, it can be seen that he was in the Fergana valley, Hujand, Tashkent, Samarkand, Kattakurgon, Hatirchi, Karmana, Nurota, Gijduvon, Bukhara, Khorezm and Turkestan. Mashrab was in in Balh and Khirot of Afghanistan, in Andhu and Shibirgon, in Pakistan and India, in Iran, Iranian Armenia,

1Shavkat Mirziyoev, the President of Uzbekistan. Cooperation in the way of peace, enlightenment and creativity. "Xalq So`zi" newspaper, October 19, 2016. 
Iraq, Turkey, Syria, Saudi Arabia, North Yemen of Africa, in Mecca, and in Madinai Muazzama, he made a hadj, and as his spiritual mentors was said, he visited the graves of the Prophet Muhammad.

The last peregrination of Mashrab was to India through the Indian Ocean, there he transited to Afghanistan, and met with Balh and Kunduz governor Makhmudbi, in the dialogue with Makhmudbi he told about injustice, imposition, sufferings of his people, that he led the country to the poverty, at the end he was hung by the decree of the ruler in 1711 in Kunduz.

Boborakhim Mashrab left an immense of socio-spiritual heritage as gazals, mustazods (long verse), muhammases, and murabbas.

Mashrab's works include "Mabdainur" and "Kimyo"("Chemistry") poems. "Mamdainur" (Starting point of the Light) in the concept of Sufism means Allah gives shine to the Light that illumines the world and the hearts of the people.

"Kimyo" is a religious, philosophical, ethical-enlightenment work, and its content consists of 22 chemistries and 37 stories.

"Mabdai Nur" and "Kimyo" are complex philosophical books that interpret the perfection of the Holy's way. These books describe the beginning and the end of humanity. This is an ideological aspect of these books to reach the truth, to recognize oneself, to return to its originality, human being should pass the sea of difficulties, otherwise to get rid of satanic illusions and to adorn themselves with all the beautiful human qualities.

Mashrab was a rebellious creator in the Uzbek literature, and philosophy history, who had created a unique style in poetry while the development of social thought. A very bright and vital picture of grace, elegance, joy, sorrow, and grief characterizes the poet's gazals. His poetic lines charmed and conquered the spirit with deep sense, playfulness, and beauty.

The father of a great poet and thinker died when Mashrab was a young boy. His father took him to the mulla Bozor Ohundto literate him, but unlike other students Mashrab recited and mastered the Koran faster, and teacher noticed him and loved.

He thought his poems would serve the people. From this point, the most prominent morality of the poet was that "Till father will not be pleased, your repentance will not be accepted".

Mashrab likened his father to the candle for the crystal of his eyes that lighted clearly and brightly. He said that until one learned faith from his 
father, "there would never be prosperous". The poet claimed, "Don't harm your neighbor, never do thingsGod does not like, when your head is up to heaven, and your father does not please you, confess and obtain consent from your father". From the earliest times, the people of the East, especially Muslims, admit that "Father will, God will". No one looked at his father's face, nor brought sufferings.

No matter how long Mashrab traveled the world, he always remembered his father. In fact, mulla Vali was in Mashrab praying with his son. As the poet said that even you read the Koran in the night and day, pray to Allah from the morning to the evening, "Till father will not be pleased, your repentance will not be accepted".

Even if you build up thirty-three thousand honakokh (chapels) by yourself, even if you build your faith in the religion, even if Jesus Christ prayed for you, even if your mentor Huja Hizr be with you, they could not stand for you, that is why your father would be pleased"- he said.

There is a saying that the cheapest thing is tastes. Cheap ceramic dishes are quick to break. When the earth becomes as a shadowy creature, it does not shrink back. Mashrab said that it did not matter how many days and nights you studied, if you did not have faith, you could not achieve perfection.

If you would like to please your father in both worlds, in that world and in this world of the four parts (four caliphs Abu Bakr, Umar, Usman, Ali) and also the Prophet Rasulullokh, together, with the saints, kings, proprietors, slaves, will pray for you, even so they will not exceed your father's pray. You should be a son as your father taught you. When you were young, your father taught you to be a man of word and spread goodness to people, but todaywhen you set foot on the wrong path he admonished, "What is wrong with your loyalty?

Heaven is not happy about how people look after their fathers. The humanity of the child to the father is above all and exalted. Therefore, be aware of your father, and call for the children not only pray, and devote themselves to God's way, but, "Worship is in vain, and you will never find it"-he said.

Do your best to keep yourself of sitting in front of your parents and good people, keep your body clean and keep yourself as a slave, so that you can reach your goal. 
Ethnic purity in the worldview of Mashrab was showed by the fact that a child has been born owing to parents, so the child shouldn't betray his parents, if he considered himself clever, and if he respected his parents, he would notget into trouble, because none of meditative plant could replace the treatment, those who cause torments to fathers could not be under the protection of God, and would turn away from them.

Mashrab was always traveling, and he considered his duty to look after his parents, putted humaneness in priority, wrote letters to them and aspired to them. mulla Vali and Bibi Salimas were also aware of the state of Mashrab and the place where he was going to live, and they were happily welcomed by their children every time. Father also urged a lyric hero, a former student, to respect his father, listen to him, fulfil his duty as a righteous child, and urged him to make his father pleased, "Till father will not be pleased, your repentance will not be accepted".

Imam Ismail Bukhari says in his book Al-adab al-mufrad: "Obey your parents if they say to abandon the world, execute this for their respect!"2 First, children need to respect the mother. It is narrated in hadith of At-Termizi that the Prophetthought: "Ibn Hakim said that his father said to his grandfather from his grandfather, "Ibn Rasululloh! (Messenger of Allah)-I said, - "Whom Should I bring goodness?" Rasululloh said, "Your mother." "To whom else?" I asked: "To your mother" "To whom else?" I asked. He said: "To your father", "Then to all your relatives"3.

Mashrab in the center of his social and moral heritage placed relation to parents.

It is a great happiness to be the mother of a poet Mashrab. Mashrab always remembered his mother, wherever he was. At the same time, the mother's heart was full of bitterness and sadness. She was a miserable, and her heartwas wounded and bleeding. She was burned for her baby. After all, Mashrab who was the only child of his mother, traveled a far along in the deserted countries and villages to look for justice. Because of his journeys and searches of the truth, Mashrab could not care and know about his mother constantly. A poet who went around the globe wrote:

I have come to see you, my dear mother,

My mother suffered for me and her heart was bleeding.

\footnotetext{
2 Imam Ismail Al-Bukhari. Al-adab al mufrad. "Uzbekistan", Tashkent, 1990, p. 11.

${ }^{3} \mathrm{Abu}$ Isa Termizi. Sahih al-Termizi. "Uzbekistan", Tashkent, 2004, p 42.
} 
You are a beautiful kindness; you are the peace of my soul,

You are my worlds, heaven and hell, dear mummy.

The poet, who was on his journey, always seeked his mother. Heaven is one. However, for the sake of Mashrab, there are two paradises. The true paradise is free of sin; it is eternal for God's innocent servants. For Mashrab come to mother was similar to enter the paradise. Because the son finds rest in his mother's presence, the poor poet felt himself in two worlds when he visited his mother. The hadith states: "Paradise is under the feet of mothers." Mashrab emphasized his mother's kindness.

He compared Bibi Salim to the Kabah. The Kabah is a holy place where believers and Muslims visit. House of Kabah is a place of worship. Mashrab is the perfect person who has the happiness of visiting the Kabah several times, so he said that he had come to the Ka'bah and had come to do tawof(pilgrimage). Since for the walking poet see the mother, who was waiting for him to open her heart, and tell him sorrows, was the same with visiting the Kabah. Mashrab invokes God to forgive him because he could not take care and visit his mother.

Mashrab's writings showed that his teacher, Ofokhoja, had a great deal of service, and when the poet passed through the country, the crowds and the rulers warmly welcomed him, but because of some immoral acts, he made them anger, and he said the following about his popularity among the people:

Mashrab, who spent seven years with Ofokhoja, under one roof, because of his love for man was punished and deported. From this day the poet's legends and narratives had begun. Whenever he was hardworking, people would respect him. Before Mashrab came to the city or village, people went outside in the hope. The dervish poet read the gazals before them and honoured by the people for his extraordinary and extremely knowledge. Many people were eager to be disciples, and the rulers were eager to be murid (follower of the Pir). However, Mashrab, who was aware of his reputation and excessive popularity, for some of his immoral acts, got their anger and hatred. Only the number of mutasavvifs (theorist of Sufism) can explain the reason of this. Mashrab, Ibrakhim, Adkham and Mansur Khalloj, followed him, pledged their devotion to Allah, and followed the doctrine of "Love is the only Truth". It was Mashrab's main idea, the concept that "People who love me can weaken their sympathy for Allah". Therefore, 
among the people he was called "Devonai Mashrab", "TelbaMashrab", "Shoh Mashrab", "Devonai Barhak". 4

Boborakhim Mashrab wrote that the French and Germans were highly appreciated his works, by the fact, his poetry was translated from the 19th century in the West and Europe, and his poems were translated and interpreted by the western literature experts. The study of the life and work of Boborakhim Mashrab in the East began in his lifetime, but in Western Europe, consecutive and scientific study began in the nineteenth century.

We know that the works of many great Eastern writers had been translated and widely studied in Western languages. Shortly after the death of the great poets such the kings of the words as Alisher Navoi, Zakhiriddin Babur, Khofiz Sherozi, Fuzuli, they entered the Western literary world. However, the creator of beautiful, playful, melancholy, broad-minded gazals, Mashrab, even was not accepted in Europe? However, the results of our further research showed that the works of our compatriot as Navoi and Fuzuli's had the same ideas with Western literature experts. The gentle Frenchman, the Germans, and the venerable Hungarian highly appreciated the life and works of Boborakhim Mashrab. ${ }^{5}$

Russian scholars who made a great contribution to Mashrab's research, such as N.S Veselovsky, V.L. Vyatkin, U.E. Ostroumov highly appreciated N.S.Likoshi services, and researchers as Herman Vamberi, Martin Hartman, Bernard Grenar, Ditrel de Ren, Johannes Avetaranian, a member of the American Academy of Sciences, German orientalist Annamarie Shimmel, made their hard work in this sphere.

Great German orientalist, Arabic, Persian, Turkish, and especially Uzbek language specialist, Islamic scholar A. Shimmel, along with many mutasavvifs were also studied Mashrab's tasavvuf (science based on study of spiritual experience) views. Shimmelin the book "The Silk Road Heritage" in to the German and Uzbek section with honour mentioned names of the German orientalist M. Hartman and the Hungarian orientalist H.Vamberi, who made a great contribution in researches of Boborakhim Mashrab. ${ }^{6}$

It was emphasized by Russian academics E.E.Bertel, I.Yu.Krachkovsky and other scientists.

"Musa Tojikojayev. Studying the life and work of Boborahim Mashrab abroad. "Adabiyot ko 'zgusi". The publishing house named after Abdulla Qadiriy № 5. Tashkent, 2000, p. 170

5 The same resource, pages 171.

6 The same resource, pages 171-172.

Social science and humanities

Generalization of scientific results 
"Layla and Majnun" is one of the most mournful stories about love in world literature. Comparing this novel to Romeo and Juliet, a well-known Arabist, academician I.Yu.Krachkovsky said:

"According to the story of Romeo and Juliet, which was perpetuated by William Shakespeare in the West, there are no more sorrowful stories in the world.

The East, of course, did not know Romeo and Juliet and met them only in the 19th century, but the story of Layla and Majnun, what lived for centuries, had inspired dozens of great poets to create romantic poems, and even today, it reflects in many works of poets, play writers, and musicians. As the reputation of Romeo and Juletta is famous in the west, so Layla and Majnun, is famous in the east ... ".

The Russian orientalist's scholars gave a high estimation to Navoi's poems about Leyla and Majnun. It should be noted that Boborakhim Mashrab, who enjoyed the poetry of Alisher Navoi, learned that he had been inspired by divine love and that he had known Allah, that he had received books from Layla's mole, had reached the people from Majnun, and to show his sufferings addressed like "do not grab my sorrows" "you are not educated do not read my notes" and wrote the following gazal:

Hey breeze, I am in a sorrow, do not touch my bed,

I am in a horizon, do not touch my ashes.

Every time I receive books from Layla,

If you are not Majnun, do not touch my notes.

That Majnun passed the path and I passed it too,

Every time I am in the agony with you, let me call Layla.

The thinker Mashrab, explained the Divine love of Layla and Majnun with philosophical interpretation, expressed their morals in high poetry, emphasizes that the perfect man should be honest in the way of love (Divine love) and sacrifice for it. He thought that if the baby does not cry, his mother would not give a milk, so love must be clean like the mother's breast milk:

It is a man the same man, who cares,

Not the one but all the world just watches.

Mashrab's love sufferings about amorous Majnun and beloved Layla, the Great A. Navoi described in the end of his poem "Layla and Majnun",

7И.Ю.Крачковский. Ранняя история повести о Меджуне и Лейле в арабской литературе, Сб. “Алишер Навои”, изд. АН СССР, М.,-Л., 1946. стр. 31. (І.Yu. Krachkovskiy. History about Madjun and Leyli in Arabic literature. "Alisher Navoi" 1946. P. 31.) 
this love story would not come true on the earth, it would be eternal, being cerement in a grave, a coffin a tomb, it would be free and clean from the morning to the Judgement Day.

Layla entrusted her mother before her death and pleaded that Majnun would come to this place and would not hurt her. Whenever her love mate came into the house and they saw each other, it was the only what they wished.

As Layla sacrificed her life and died, so Majnun sacrificed his life and died. Layla lost her eternity sleep and reached her love mate, and Majnun followed her and sacrificed his life.

The essence of Mashrab's social and moral views was an attitude towards the system of the XVII-XVIII centuries, he was dissatisfied with the system, injustice, oppression, fought against scarcity, and as an educated, comprehensively creative person, he could foresee the undesirable mood of the rulers, and tried to diminish tyranny by his eloquent pen.

Another noteworthy aspect of the socio-political views of the thinker was that he criticized the negative aspects of his time, and called on people to be educated, get knowledge and handcraft skills, and urged cruel and ignorant, fraudsters and immoral people to be fair and honest.

The basis of Mashrab's socio-ethical views is the idea of encouraging people to get knowledge and to be educated. He was very creative for his time; he created stories, ethical-enlightening gazals. They promote love and moral perfection, but sharply condemn injustice and hypocrisy, and encourage people to live in harmony and cohesion.

Mashrab propagated purity and honesty, diligence, respect for his parents, patriotism and self-sacrifice, and he fought for justice, good and fair, high faith and truth. His ethical views, which have been fed by a national and universal spirit, have not yet lost their educational significance.

In the history of socio-ethical thinking of the Uzbek people, Mashrab's service is vast. His beautiful and unique gazals opened another page in the development of the spiritual life of the Uzbek people. The spirituality that Mashrab fond of is its inner tune, beauty, elegance, philosophy. The beauty of the pure admiration of the thinker, that spiritreached us through the centuries and lives with us.

Mashrab's poems are diverse and poetic. His work is a bright page in the history of the Uzbek literature. The poet "burned down" and lived with fire, who burned with fire and worked with chilly words. By the ability to 

sing people's sorrows, to create exciting works, with a strong style of lyric poetry, with his delicacy, fervent and clear sounds of his songs, because of his exceptional talent, he deserved the people's love, and took a deep place in the hearts of the people.

Thanks to our Independence, a significant positive change in the attitude towards true folk poet Boborakhim Mashrab and his rich literary heritage was achieved.

Mashrab was a wise, intelligent man of his time, who was deeply learned in religious and secular sciences. He had never been able to be in a good relations with fanatical priests and rulers. The ridiculousness, injustice and cruelty of these people, who are interested in keeping the people in ignorance and fear, had filled the heart of Mashrab with hatred towards them. Mashrab was not a weak person who was able to overwhelm his anger and suffer or pain from injustice. He was a brilliant, brave man, who had a great deal of wisdom and imagination. Mashrab was not one of the poets who, couldwalked aside without questionwhen he saw injustice. He was shamelessly oppressing the tyrant rulers, who had been making mischief the people, condemn the people, frighten them, and torture them. Mashrab was guilty in incriminating evidences that these individuals had hidden from the people, their indifference and indisputable arguments. He had always been victorious over opposers.

The magnificence of the spiritual ability of Mashrab and his oppression ofinjustice horrified theruling elite. That is why they killed Mashrab. Those who succeeded in physically assaulting Mashrab could not deprive his spirituality, destroy the love from the people's hearts.

Mashrab was a lifelong man, and he was in the true world and expressed his spirit in his own way. That's why the philosophy and ethical heritage of the thinker, his philosophical and spiritual insight, has not been losing its educational significance to this day. 


\section{References}

Shavkat Mirziyoev, the President of Uzbekistan. Cooperation in the way of peace, enlightenment and creativity. "Xalq So zi" newspaper, October 19, 2016.

Imam Ismail Al-Bukhari. Al-adab al mufrad. "Uzbekistan", Tashkent, 1990, p. 11.

Abu Isa Termizi. Sahih al-Termizi. "Uzbekistan", Tashkent, 2004, p 42.

Musa Tojikojayev. Studying the life and work of Boborahim Mashrab abroad. "Adabiyot ko 'zgusi". The publishing house named after Abdulla Qadiriy № 5. Tashkent, 2000, p. 170

И.Ю.Крачковский. Ранняя история повести о Меджуне и Лейле в арабской литературе, Сб. “Алишер Навои”, изд. АН СССР, М.,-Л., 1946. стр. 31. (I.Yu. Krachkovskiy. History about Madjun and Leyli in Arabic literature. "Alisher Navoi" 1946. P. 31.) 